\title{
Secondary Metabolites from Marine-Derived Fungi and Actinobacteria as Potential Sources of Novel Colorectal Cancer Drugs
}

\author{
Elin Julianti ${ }^{1, *}$, Ikram Ammar Abrian ${ }^{1}$, Marlia Singgih Wibowo ${ }^{1}$, Muhammad Azhari ${ }^{1}$ (D) Nadya Tsurayya ${ }^{1}$ (D), \\ Fauzia Izzati $^{2}$ (D), Ario Betha Juanssilfero ${ }^{2}$, Asep Bayu ${ }^{2}$, Siti Irma Rahmawati ${ }^{2}$ and Masteria Yunovilsa Putra ${ }^{2, *(D)}$
}

\section{check for}

updates

Citation: Julianti, E.; Abrian, I.A.; Wibowo, M.S.; Azhari, M.; Tsurayya, N.; Izzati, F.; Juanssilfero, A.B.; Bayu, A.; Rahmawati, S.I.; Putra, M.Y. Secondary Metabolites from Marine-Derived Fungi and

Actinobacteria as Potential Sources of Novel Colorectal Cancer Drugs. Mar. Drugs 2022, 20, 67. https://doi.org/ $10.3390 / \mathrm{md} 20010067$

Academic Editor: Marc Diederich

Received: 25 November 2021

Accepted: 10 January 2022

Published: 12 January 2022

Publisher's Note: MDPI stays neutral with regard to jurisdictional claims in published maps and institutional affiliations.

Copyright: (C) 2022 by the authors. Licensee MDPI, Basel, Switzerland. This article is an open access article distributed under the terms and conditions of the Creative Commons Attribution (CC BY) license (https:// creativecommons.org/licenses/by/ $4.0 /)$.
1 School of Pharmacy, Bandung Institute of Technology, Jl. Ganesha No.10, Bandung 40132, Indonesia; ikramammarabrian@gmail.com (I.A.A.); marlia@fa.itb.ac.id (M.S.W.); mazhari@fa.itb.ac.id (M.A.); tsurayya.nadya@gmail.com (N.T.)

2 Research Center for Biotechnology, Research Organization for Life Sciences, National Research and Innovation Agency (BRIN), Jl. Raya Jakarta-Bogor KM 46 Cibinong, Bogor 16911, Indonesia; fauzia.nurul.izzati@brin.go.id (F.I.); ario.betha.juanssilfero@brin.go.id (A.B.J.); asep.bayu@brin.go.id (A.B.); siti.irma.rahmawati@brin.go.id (S.I.R.)

* Correspondence: elin_julianti@fa.itb.ac.id (E.J.); masteria.yunovilsa.putra@brin.go.id (M.Y.P.)

\begin{abstract}
Colorectal cancer is one of the most common cancers diagnosed in the world. Chemotheraphy is one of the most common methods used for the pharmacological treatment of this cancer patients. Nevertheless, the adverse effect of chemotherapy is not optimized for improving the quality of life of people who are older, who are the most vulnerable subpopulation. This review presents recent updates regarding secondary metabolites derived from marine fungi and actinobacteria as novel alternatives for cytotoxic agents against colorectal cancer cell lines HCT116, HT29, HCT15, RKO, Caco-2, and SW480. The observed marine-derived fungi were from the species Aspergillus sp., Penicillium sp., Neosartorya sp., Dichotomomyces sp., Paradendryphiella sp., and Westerdykella sp. Additionally, Streptomyces sp. and Nocardiopsis sp. are actinobacteria discussed in this study. Seventy one compounds reviewed in this study were grouped on the basis of their chemical structures. Indole alkaloids and diketopiperazines made up most compounds with higher potencies when compared with other groups. The potency of indole alkaloids and diketopiperazines was most probably due to halogen-based functional groups and sulfide groups, respectively.
\end{abstract}

Keywords: marine; fungi; actinobacteria; colorectal cancer; cytotoxicity; secondary metabolite

\section{Introduction}

As the third deadliest cancer, colorectal cancer (CRC) is the fourth type of cancer most diagnosed in the world. By 2018, there were approximately 704,000 new cases of rectal cancer and more than a million new cases of colon cancer diagnosed, summing up to 1.8 million new cases in CRC [1]. Chemotherapies are the most common method for medical treatment of CRC's patients. Despite the advances in CRC medical treatments, this medication still faces two main issues regarding cancer chemotherapy resistance and the dilemma of specific CRC pharmacotherapy for people who are older, as the most vulnerable subpopulation.

CRC chemotherapy resistance could occur through the variety of gene expressions for related proteins. For instance, the effectiveness of fluorouracil (5-FU) on targeting thymidylate synthase, is highly correlated with the presence of the thymidylate synthase enzyme. The 5-FU effectiveness is also related to its metabolism and degradation by specific proteins such as thymidine phosphorylase, uridine phosphorylase, orotate phosphoribosyl transferase, and dihydropyrimidine dehydrogenase [2]. The expression of the Rac1b gene is overexpressed in the adenocarcinoma form of colon cancer. The overexpression of the 
Rac1b gene is shown to facilitate chemoresistance against treatment with oxaliplatin or 5-FU through NF-kB signaling [3]. Thus, chemotherapy alone is sometimes insufficient for the treatment of CRC. The mechanism of resistance must be addressed to have a successful treatment outcome.

Additionally, people who are older are the most vulnerable subpopulation of CRC, with a high incidence among elders above 70 years of age. Since each of them has different medical conditions, personalized CRC pharmacotherapy should be addressed and their treatments need to be more specific and should consider the complications of chemotherapy, radiotherapy, or surgery with respect to their frailty, cognitive and functional status, and any related comorbidity that comes along [4].

Exploring alternative sources of active pharmaceutical ingredient (API) for CRC therapy is critical to finding more effective strategies for managing those two issues. Natural compounds from plants have historically occurred in cancer treatment. For examples, irrinotecan (CPT-11) has been used for CRC treatment after the failure of 5-fluorouracil treatment [5-7]. Furthermore, andrographolide is a diterpene lactone isolated from the plant Androphagis paniculata, which induces the apoptosis of HCT 116 cells in combination with 5-FU [8]. Curcuma longa produced curcumin, a polyphenol compound, that induced p21-independent and reduced the secretory level of TNF- $\alpha$, with significantly improved the quality of life of the patients $[9,10]$. Marine organisms were also shown to be potential sources for novel compounds against CRC. In addition, a sulfated polysaccharide from brown seaweed, namely fucoidan, displayed apoptosis activity in HCT-116 and HT-29 cells [11]. Moreover, fucoidan has significant activity against CRC, with relatively little side effects for humans in clinical trials [12].

Recently, the exploration of novel anticancer agents against CRCs derived from marine microbiology has attracted much attention. Marine microbes such as fungi, algae, bacteria, and plankton make up to $98 \%$ of the biomass within the world's seas [13]. With the advancement of marine biotechnological techniques, several papers revealed the high potency of mining marine microorganisms for bioactive compounds. Among of them, bacteria and fungi are the prime targets for studies regarding the production of novel bioactive metabolites [14]. In contrast with the oversaturation of API discovery from terrestrial-based microorganisms, marine microorganisms still remain limited in exploration and offer high potency to obtain novel active compounds.

A previous study demonstrated that polyunsaturated fatty acids (PUFAs) from marine microalgae have strong inhibition against the HT-29 cell line [15]. Nowadays, some marine compounds from fungi and actinobacteria show significant activity against CRC cell lines. The research and development on drug discovery based on marine microbes, including for active compounds against CRC, offer a huge potency because these microorganisms could be cultivated as well as modified for large-scale production. Therefore, this paper performs a descriptive study on the discoveries of novel compounds isolated from marine microbes such as fungi and actinobacteria collected from various marine sediments and seawaters. This literature review was conducted by selecting the possibility of becoming alternative agents against CRC concerning cytotoxicity studies.

\section{Potential Cytotoxic Metabolites from Various Marine Microorganisms against CRC}

\subsection{Marine Fungi}

\subsubsection{Aspergillus sp.}

Rosellichalasin (1) and Cytochalasin E (2) are two alkaloids isolated from Aspergillus sp. nov. F1 (Figure 1). This fungus was obtained from a marine solar saltern in Weihai, China [16]. Both compounds belong to a classification of fungal metabolites known as cytochalasins, which suppress cell division and instigate apoptosis through their actions on a cellular level of degradation and formation disruption of actin filaments [17]. In an MTT assay, these compounds showed moderate and weak activity, with $\mathrm{IC}_{50}$ values of 62.3 and $37.3 \mu \mathrm{M}$ against the RKO CRC cell lines, respectively. The $\mathrm{IC}_{50}$ values of cytochalasins 
were significantly lower than that of ergosterol, which managed to have an $\mathrm{IC}_{50}$ value of $3.3 \mu \mathrm{M}[16]$.

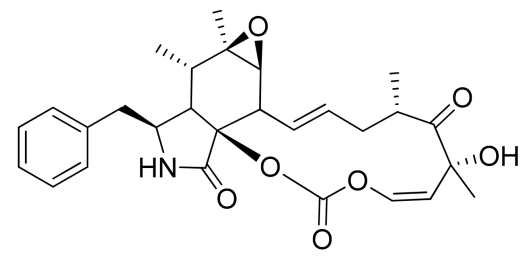

1<smiles>C/C=C/C[C@H](C)C(=O)/C(C)=C\CC(=O)O[C@]12C(=O)N[C@@H](Cc3ccccc3)[C@H]1[C@@H](C)[C@]1(C)O[C@@]12C</smiles>

2<smiles>COc1cc2c(c(O)c1Cl)C(=O)c1c(cc(OC)c(Cl)c1OC)C2C1c2cc(C[C@H](C)O)cc(O)c2C(=O)c2cc(C[C@H](C)O)cc(O)c21</smiles>

3<smiles></smiles>

4<smiles>COC1=C(Cl)C(O)C2C(=O)c3c(O)cc(C[C@@H](C)O)cc3[C@H](C3c4cc(C[C@H](C)O)cc(O)c4C(=O)c4c3cc(OC)c(Cl)c4O)C2=C1</smiles>

5<smiles>CCCCCCCCCC(O)CC(=O)NC(CC(N)=O)C(=O)N[C@@H](CCC(N)=O)C(=O)NC(CCC(C)C)C(O)O</smiles><smiles>CCCCCCCCCC(O)CC(=O)NC(CC(N)=O)C(=O)N[C@@H](CCC(N)=O)C(=O)N[C@@H](CO)CC(C)C</smiles><smiles>Cc1cc(O)c(C(=O)c2c(O)cccc2O)c(C(=O)C[C@@H](CC(C)C)NC(=O)[C@H](CCC(N)=O)NC(=O)[C@H](CC(N)=O)NC(=O)CCO)c1</smiles>

$8: 17 R$

$9: 17 \mathrm{~S}$

Figure 1. Chemical structures of compounds 1-9.

The co-culture from two different growth stages of a new strain of Aspergillus alliaceus, coined as the G4 strain, was successfully reported to produce several potent bianthrones: allianthrones A (3), B (4), and C (5). An MTT assay against HCT-116 (CCL-247) CRC cells resulted in $\mathrm{IC}_{50}$ values of $9.0,10.5$, and $13.7 \mu \mathrm{M}$, respectively, which are more potent than the $11.6 \%$ survival rate of HCT-116 cells treated with $250 \mu \mathrm{M}$ of etoposide as a positive control [18].

The lipopeptides fellutamide F (6) and fellutamide C (7) were obtained from a symbiotic fungi Aspergillus versicolor PF10M of a marine sponge of Petrosia sp. from the coastal area of Jeju Island, Korea [19]. These compounds were also reported to be isolated from Penicillium fellutanum, a fungus associated with saltwater fish. Compound $\mathbf{6}$ and its counterpart, compound 7, exhibited potent cytotoxicity against HCT-15, with ED 50 values 0.13 and $1.74 \mu \mathrm{g} / \mathrm{mL}$, respectively. The former substance showed cytotoxic activities higher than that of doxorubicin. It is structurally similar to the hydrated version of fellutamide B [19], found from P. fellutanum from the belly of the fish Apogon endekataenia located within the waters of the Japanese coast. The compound is also a cytotoxic agent against human epidermoid carcinoma cells KB [20] and is a known proteasome inhibitor [21]. 
The isolation of secondary metabolites from the fungus Aspergillus versicolor Ppf48 yielded several compounds, including asperphenin A (8) and asperphenin B (9) [22]. Through an SRB assay and tested upon RKO CRC cell line, compounds 8 and $\mathbf{9}$ showed strong cytotoxic activities, with $\mathrm{IC}_{50}$ values of 0.84 and $1.26 \mu \mathrm{M}$, respectively. Compounds 8 and 9 hold significance as comparative treatments compared with the positive control of etoposide, with an $\mathrm{IC}_{50}$ value of $3.82 \mu \mathrm{M}$.

Compound 8 attacks the RKO CRC cells in various ways. Notably, the aryl ketone of C7 of both asperphenins is the primary cause of decreased cell viability. Treatment of this compound against RKO cells is correlated with the cells' accumulation toward the sub-G1 apoptotic phase. It also increased G2/M phase arrest, induced ROS, and suppressed tubulin polymerization. Moreover, it was observed to induce the decrease in RKO tumor cells volumes in xenograft mice, which can reach lower percentages when combined with irinotecan.

\subsubsection{Penicillium sp.}

The isolation of secondary metabolites from Penicillium paneum SD-44 obtained the anthranilic acid derivatives penipacids A-E (10-14) and one synthesized analogue (15) (Figure 2). Compounds $\mathbf{1 0}$ and $\mathbf{1 4}$ revealed inhibitory activity against RKO CRC cells using the MTT assay, obtaining $\mathrm{IC}_{50}$ values of 8.4 and $9.7 \mu \mathrm{M}$ [23]. The $\mathrm{IC}_{50}$ values were significantly lower than the positive control agent, fluorouracil, which has an $\mathrm{IC}_{50}$ value of $25 \mu \mathrm{M}$. Assays of anthranilic acid and its derivatives for their anticancer potential have been studied on several occasions. For instance, an initial in vitro and in vivo effect of anthranilic acid on cancer cells exhibited that the flufenamic acid patterns allow for the presence of functional groups such as (hetero)aryl esters to improve the in vitro tumor cell growth suppression [24].

Brocazines A-F (16-21) were obtained from endophytic fungus Penicillium broca MA231, which was isolated from marine mangrove Avicennia marina tissue from Hainan island, south of Mainland China. Compounds 16 and $\mathbf{1 7}$ exhibited $\mathrm{IC}_{50}$ values of 2.0 and $1.2 \mathrm{nM}$, respectively, against SW480 (CCL-228) CRC cells. The results showed high cytotoxic activity when compared with the positive control, cisplatin, having an $\mathrm{IC}_{50}$ value of $11.3 \mu \mathrm{M}$. Both compounds also showed comparatively stronger activity against NCI-H460 (human large-cell lung carcinoma), SGC-7901 (human gastric carcinoma), and U251 (human glioma cell) cell lines compared with the positive control cefitinib and doxorubicin. The cytotoxic activity was based on the presence of the disulfide bridge within the compound's structures [25]. Similar diketopiperazines with disulfides can cause cytotoxicity against HCT116 CRC cell lines [26]. The apoptosis caused by diketopiperazine disulfides was shown through Annexin V-propidium iodide staining via flow cytometry. In terms of a dose-response relationship, the number of cells at various stages of apoptosis is directly proportional to concentrations of diketopiperazine disulfides. Treatment of such class of metabolites also correlates with the cleavage of poly (ADP-ribose) polymerase (PARP) and caspase proteins within apoptotic cells as well as with the downregulation of mitochondrial apoptosis allosteric regulators (e.g., Bcl-xL and Bcl-2 anti-apoptotic agents) and the upregulation of pro-apoptotic agents (e.g., Bax). 
<smiles>[R]C(C)(C)CN=C(C)Nc1ccccc1C(=O)O</smiles>

$10 \mathrm{R}=\mathrm{OH}$

$11 \mathrm{R}=\mathrm{OMe}$<smiles>[R]OC(=O)C/N=C(\C)Nc1ccccc1C(=O)O</smiles>

$12 \mathrm{R}=\mathrm{H}$ $13 \mathrm{R}=\mathrm{Me}$<smiles>O=C(O)c1ccccc1N/C=N/c1ccco1</smiles>

14<smiles>CC(=O)C(C)=Nc1ccccc1C(=O)O</smiles>

15

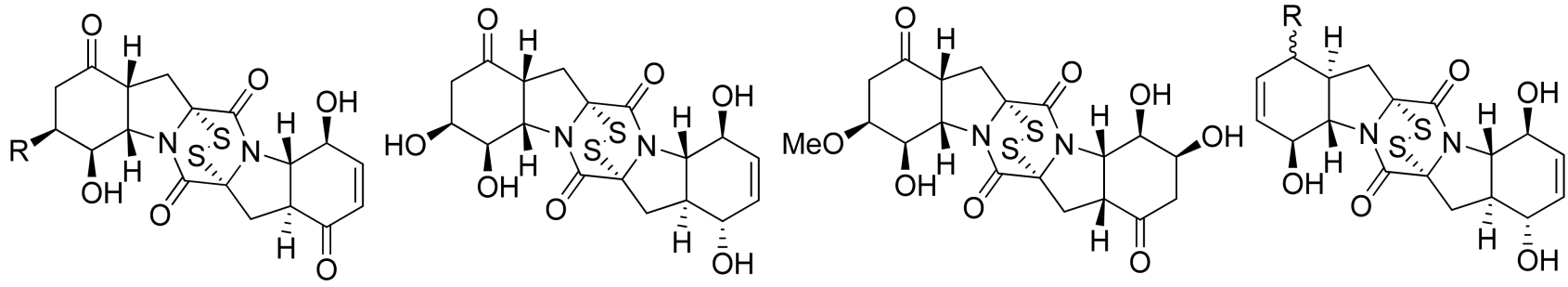

$16 \mathrm{R}=\mathrm{OMe}$

18

19

$20 \mathrm{R}=\alpha-\mathrm{OH}, \beta-\mathrm{H}$

$21 \mathrm{R}==\mathrm{O}$<smiles>CN1C(=O)[C@@]2(CO)NC(=O)C1(Cc1ccccc1)N2C</smiles>

28

29<smiles>[R]Oc1cc(C)cc(Oc2cc(C)cc(O[R])c2)c1</smiles>

$32 \mathrm{R}_{1}=\mathrm{CH}_{3}, \mathrm{R}_{2}=\mathrm{H}$

33

$26 \mathrm{R}_{1}=\alpha-\mathrm{OMe}, \mathrm{R}_{2}=\alpha-\mathrm{OH}$

$23 \mathrm{R}_{1}=\alpha-\mathrm{OMe}, \mathrm{R}_{2}=\mathrm{O}$

$24 \mathrm{R}_{1}=\beta-\mathrm{OH}, \mathrm{R}_{2}=\mathrm{O}$

$27 \mathrm{R}_{1}=\alpha-\mathrm{OH}, \mathrm{R}_{2}=\alpha-\mathrm{OH}$

30<smiles>C/C=C/C=C(\C)C(=O)NC(CO)CC(C)C</smiles><smiles>CC(=O)c1nc(C(N)=O)cc2c1[nH]c1ccccc12</smiles>

36<smiles>COC(=O)Cc1c[nH]c2ccccc12</smiles>

35<smiles>C=C(C)NC</smiles>

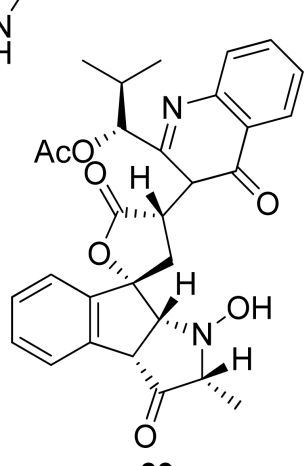

39

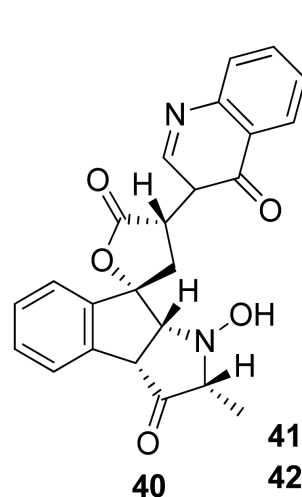

$41 \mathrm{R}_{1}=\mathrm{R}_{4}=\mathrm{H}, \mathrm{R}_{2}=\mathrm{CH}\left(\mathrm{CH}_{2}\right)_{3}, \mathrm{R}_{3}=\mathrm{Me}$ $42 \mathrm{R}_{1}=\mathrm{CH}\left(\mathrm{CH}_{2}\right)_{3}, \mathrm{R}_{2}=\mathrm{R}_{4}=\mathrm{H}, \mathrm{R}_{3}=\mathrm{Me}$ $43 \mathrm{R}_{1}=\mathrm{H}, \mathrm{R}_{2}=\mathrm{CH}\left(\mathrm{CH}_{2}\right)_{3}, \mathrm{R}_{4}=\mathrm{R}_{3}=\mathrm{Me}$ $44 \mathrm{R}_{1}=\mathrm{CH}\left(\mathrm{CH}_{2}\right)_{3}, \mathrm{R}_{2}=\mathrm{H}, \mathrm{R}_{4}=\mathrm{R}_{3}=\mathrm{Me}$

Figure 2. Chemical structures of compounds 10-44. 


\subsubsection{Westerdykella sp.}

Seven new alkaloid compounds were isolated from Westerdykella dispersa XL602 fungus, collected from the South China Sea marine sediments near Guangzhou, China [27]. The isolated compounds of cytochalasans were named 18-oxo-19,20-dihydrophomacin C (22), 18oxo-19-methoxy-19,20-dihydrophomacin C (23), 18-oxo-19-hydroxyl-19,20-dihydrophomacin C (24), 19,20-dihydrophomacin C (25), 19-methoxy-19,20-dihydrophomacin C (26), 19 hydroxyl-19,20-dihydrophomacin C (27), and the tyrosine-derivative, gymnastatin Z (28). When tested against HT-29 cells through an MTT assay, compounds 25, 26, 27, and 28 displayed moderate inhibitory activity, with $\mathrm{IC}_{50}$ values of $49.09,55.31,55.48$, and $49.1 \mu \mathrm{M}$, respectively.

\subsubsection{Paradendryphiella sp.}

The isolation of (-)-(3R, 6R) Hyalodendrin (29) was obtained from Paradendryphiella salina PC $362 \mathrm{H}$ fungus [28]. This compound was determined using the MTT assay against 15 different type of cancer cell lines, such as SW 48, DLD1, HT 29, HT 29 5FU, HT 29 oxa, HT 29 SN-38, HCT 116, HCT 116 5FU, HCT 116 oxa, HCT 116 SN-38, LS 513, LOVO, RKO, LS174T, and SW 480. Compound 22 revealed strong cytotoxic activity against HCT 116 oxa cells, with an IC $_{50}$ value of $25.7 \mathrm{nM}$. This compound is characterized by a sulfur-bridged dioxopiperazine that is believed to have an important role in its activity [29].

\subsubsection{Dichotomomyces sp.}

Eight compounds were isolated from Dichotomomyces cejpii F31-1 fungus associated with the soft coral Lobophytum crassum collected from Hainan Sanya National Coral Reef Reserve, China. These compounds were identified as dichotomocej A (30), diorcinol (31), 3-O-methyldiorcinol (32), butyl (2-ethylhexyl) phthalate (33), dichocerazine A (34), pityriacitrin (35), stellarine A (36), and indolyl-3-acetic acid methyl ester (37). All compounds were evaluated against HCT 116. Among them, pityriacitrin (35) exhibited a moderate inhibitory effect against HCT116 cells using the SRB colorimetric method, with an $\mathrm{IC}_{50}$ value of $35.1 \mu \mathrm{M}[30]$.

\subsubsection{Neosartorya sp.}

The marine se fan-derived fungus Neosartorya siamensis KUFC 6349 resulted in eight compounds, namely chevalone $\mathrm{C}$ (38), nortryptoquivaline (39), tryptoquivaline $\mathrm{H}(40)$, fiscalin A (41), epi-fiscalin A (42), epi-neofiscalin A (43), and epi-fiscalin C (44). These compounds tested against HCT116 cells through an MTT assay, and IC 50 values of 153, 114, $202,123,277,203$, and $86 \mu \mathrm{M}$ were obtained, respectively, for compounds $38,39,40,41,42$, 43, and 44 [31]. In the HCT116 cell line, the compounds 25, 42, and 44 slightly decrease cell proliferation (tested at $50 \mu \mathrm{M}$ ), showing cell proliferation inhibitions of $19 \%, 22 \%$, and $58 \%$, respectively. Compound 44 exhibited significant inhibition of cell proliferation and presented a promising antiproliferative effect (in comparison with doxorubicin $0.1 \mu \mathrm{M}$ and cell proliferation inhibition of $60 \%$ ) [31].

\subsection{Actinobacteria}

\subsubsection{Nocardiopsis sp.}

The discovery of a cyclic tetrapeptide named androsamide (45) was obtained from Nocardiopsis sp. CNT-189 collected from sediments around the shores on Bahamas (Figure 3) [32]. Its treatment against the Caco-2 and HCT116 cancer cell lines was noted to correlate with the decrease in their viability in a dose-dependent manner. Nevertheless, it did not possess sufficient cytotoxic, with $\mathrm{IC}_{50}$ values of 13 and $21 \mu \mathrm{M}$, respectively. Nevertheless, it showed apoptosis in Caco-2 CRC cells. Compound 45 inhibited Caco-2 cell migration in a dose-dependent manner. Similarly, the compound was able to decrease EMT transcription factors corresponding to the expression by Caco- 2 cells as well as genes related to cell motility in Caco-2, e.g., CAPN1 and RAC2. 


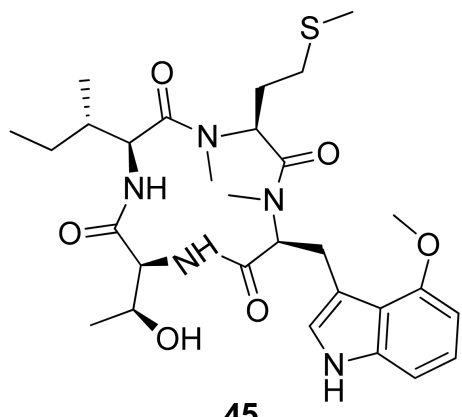

45<smiles>CCc1oc(C(C)CC)cc1C(=O)O</smiles>

50<smiles>C[C@H]1NC(=O)[C@H]2CCCN2C1=O</smiles>

46<smiles>C[C@]12CCCN1C(=O)[C@H](Cc1ccccc1)NC2=O</smiles>

47<smiles>CNCC(=O)N[C@@H](CCCNC(=O)c1cccc(O)c1O)C(=O)NC(CC(C)C)C(N)=O</smiles>

51<smiles>CC(C)[C@H]1NC(=O)[C@@H]2CCCN2C1=O</smiles>

48<smiles>CC(C)C[C@@H]1NC(=O)[C@@H]2CCCN2C1=O</smiles>

49<smiles>Cc1c(O)cc2c(c1O)C(=O)C1(Cl)CC(Cl)C(C)(C)O[C@]1(C)[C@H]2O[C@]1(C)C2CCC1(C)O2</smiles><smiles>CC(C)=CCC/C(C)=C/C[C@@]12OC(C)(C)[C@@H](Br)C[C@]1(Cl)C(=O)c1c(cc(O)c(C)c1O)C2=O</smiles><smiles>Cc1c(O)cc2c(c1O)C(=O)C1(Cl)CC(Br)C(C)(C)O[C@]1(C)[C@H]2OC1(C)C(Br)CCC(C)(O)[C@H]1Br</smiles><smiles>Cc1ccc2[nH]cc(C3=C(c4c[nH]c5cc(Cl)c(Cl)cc45)C(=O)NC3=O)c2c1</smiles>

59<smiles>COC(=O)c1[nH]c(C(C)=O)c(-c2c[nH]c3c(Cl)cccc23)c1-c1c[nH]c2c(Cl)cccc12</smiles>

60<smiles>O=C(O)c1cccc(O)c1O</smiles>

52<smiles>NC(=O)c1cccc(O)c1O</smiles>

53<smiles>Cc1occc(=O)c1O</smiles>

54<smiles>[M]OC(=O)c1[nH]cc(-c2c[nH]c3cc(Cl)c(Cl)cc23)c1-c1c[nH]c2ccc(Cl)cc12</smiles>

61<smiles></smiles>

Figure 3. Chemical structures of compounds 45-62.

\subsubsection{Streptomyces sp.}

Compounds cyclo(Pro-Ala) (46), cyclo(Pro-Phe) (47), cyclo(Pro-Val) (48), and cyclo(ProLeu) (49) were isolated from marine Streptomyces sp. collected from a rhizosphere soil in the mangrove Avicennia marina forest of Zhangzhou [33]. The compounds were tested against HCT116 CRC cells through MTT assay, wherein IC $_{50}$ values of $47.6,32.3,67.2$, and $92.6 \mu \mathrm{g} / \mathrm{mL}$ were obtained, respectively.

The unique furan-type compound (50) was isolated from Streptomyces sp. VN1 collected from sea sediment offshore at Da Nang Beach, Phu Yen Province, Vietnam. This compound was tested against HCT116 CRC cells through an MTT assay with an $\mathrm{IC}_{50}$ value of $123.7 \mu \mathrm{M}$ [34]. This unique compound was completely elucidated to be 5-(sec-butyl)-2ethylfuran-3-carboxylic acid. No reference for the nuclear magnetic resonance (NMR) data of compound (50) was available. This is the first report of the NMR spectrum and biological activity of the furan-type compound (50) produced by a marine Streptomyces sp. [34].

Cyclic dipeptides, namely, petrocidin A (51), 2,3-dihydroxybenzoic acid (52), 2,3dihydroxybenzamide (53), and maltol (54), were successfully isolated from symbiotic fungi Streptomyces sp. SBT348 from Mediterranean sponge Petrosia ficiformis, located off the shores of Pollonia, Milos, Greece [35]. Compounds 51 and 54 were tested against HT29 CRC cells through an MTT assay, and the $\mathrm{IC}_{50}$ values were observed at 5.3 and $3.8 \mu \mathrm{g} / \mathrm{mL}$, respectively. The cytotoxic effect was observed due to the inhibition of overexpressed 
microsomal prostaglandin E2 synthase-1 on HT-29 cells, which has been discussed in several studies in the literature.

The activity of cyclic dipeptides on CRC cells is comparable with that in a study of the same group of compounds isolated from a soil-based bacterium, Exiguobacterium acetylicum, which delves more profound into the anticancer mechanisms. Several cyclic dipeptides were tested against HT29 CRC cells. Apart from an increase in apoptotic cell population indicated through annexin V-FITC staining, the cyclic dipeptides are known to upregulate the expression of pro-apoptotic markers such as Bid, cytochrome-c, and caspase- 3 and to downregulate the antiapoptotic markers such as Bcl-2 [36].

Several unique compounds were obtained through isolation from Streptomyces sp. strains from several locations worldwide. Several meroterpenoids, namely, napyradiomycin CNQ525.510B (55), napyradiomycin CNQ525.538 (56), napyradiomycin CNQ525.538 (57), and napyradiomycin CNQ525.600 (58), were isolated from an actinomycete strain CNQ525 collected from marine sediment around the coast of La Jolla, California, USA. The MTS assay testing against HCT116 CRC cells showed $\mathrm{IC}_{50}$ results of 17,6 , and $49 \mu \mathrm{M}$ for compounds (55), (56), and (58), respectively. In addition, compound 57 showed weak cytototic activity [37].

Several indole alkaloids were isolated from Streptomyces strain SCSIO 11,791 from the South China Sea, such as dionemycin (59), 6-OMe-7', $7^{\prime \prime}$-dichorochromopyrrolic acid (60), lynamicin B (61), and spiroindimicin B (62). These compounds were tested against HCT116 CRC cells using an MTT assay and resulted in IC $_{50}$ values of $4.3,13.1,8.7$, and 2.2 $\mu \mathrm{M}$, respectively [38]. The significant suppression of cancer cell viability of compounds (59) and (61) was correlated with the presence of chlorine atoms on the C-6.

Two polyether compounds isolated from Streptomyces cacaoi 14CM034 were obtained from a sediment sample in Mersin Coastline, Turkey, at a depth of $8 \mathrm{~m}$. K41 A (63) and compound 64 were tested through a WST-1 assay against Caco-2 cells and resulted in IC 50 values of 7.4 and $27.9 \mu \mathrm{M}$, respectively (Figure 4 ). The activity of compound 63 is related to its structure-activity relationship, which has a highly oxygenated (O-methyl substituted) polyether framework and the presence of $4^{\prime}-O$-methyl- $\alpha$-D-amicetose (sugar) [39].

Several polyhydroxyl macrolides isolated from Streptomyces caniferus GUA-06-05-006A were obtained from around Guadalupe Island, Pacific Ocean. Compounds PM100117 (65) and PM100118 (66) (Figure 5) were tested against HT29 cells through SRB assay, which resulted in $\mathrm{LC}_{50}$ values of 3.8 and $4.1 \mu \mathrm{M}$ [40]. The marine Streptomyces sp. IMB094 isolated from marine sediment in Heishijiao Bay, Dalian, China, resulted in four compounds, namely neo-actinomycin A (67), neo-actinomycin B (68), actinomycin D (69), and actinomycin $X_{2}$ (70). Neo-actinomycin A (67) showed a very potent cytotoxic effect when tested against HCT116 CRC cells through SRB assays, with an $\mathrm{IC}_{50}$ of $38.7 \mathrm{nM}$, which was 800 times more potent than its positive control, the agent actinomycin $\mathrm{D}(69)$ [41].

The activity of compound (67) might be due to the presence of a carboxyl group that can attack the DNA of colon cancer cells. More importantly, with compound (67), there is an absence of planarity of its tetracyclic chromophore, the distinct $5 \mathrm{H}$-oxazolo[4,5b]phenoxazine part of its structure, and the presence of a 2-amino group. These groups are thought to interact with the DNA of the affected CRC cells, disrupting the structure through the addition of hydrogen bonds bound to their cytosine subunits [41].

The cytotoxic effects of a cyclic peptide isolated from Streptomyces sp. SNJ042, ohmyungsamycin A (71), was tested through an SRB assay against HCT116 cells and resulted in an $\mathrm{IC}_{50}$ value of $7.61 \mu \mathrm{M}$, with the positive control etoposide giving an $\mathrm{IC}_{50}$ value of $0.52 \mu \mathrm{M}$. In terms of mechanisms, the study reported that compound 71 activity against HCT116 cells was through the caspase-mediated apoptosis, as indicated by the increase in sub-G1 phase cells in a dose-dependent manner. Moreover, compound $\mathbf{7 1}$ increased the cleavage of PARP by caspase activity. In a concentration-dependent manner, was also correlated with the decreased expression in Skp2, an oncogenic regulator overexpressed in tumor cells, and the increased expressions of p21 and p27, which are CDK inhibitors that function for G0/G1 cell cycle arrest [42]. 


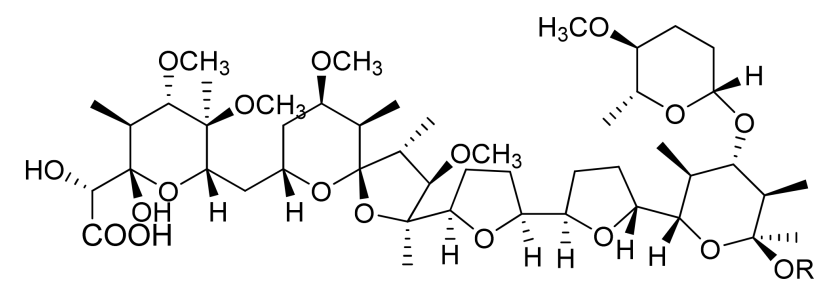

$63 \mathrm{R}=\mathrm{H}$

$64 \mathrm{R}=\mathrm{CH} 3$

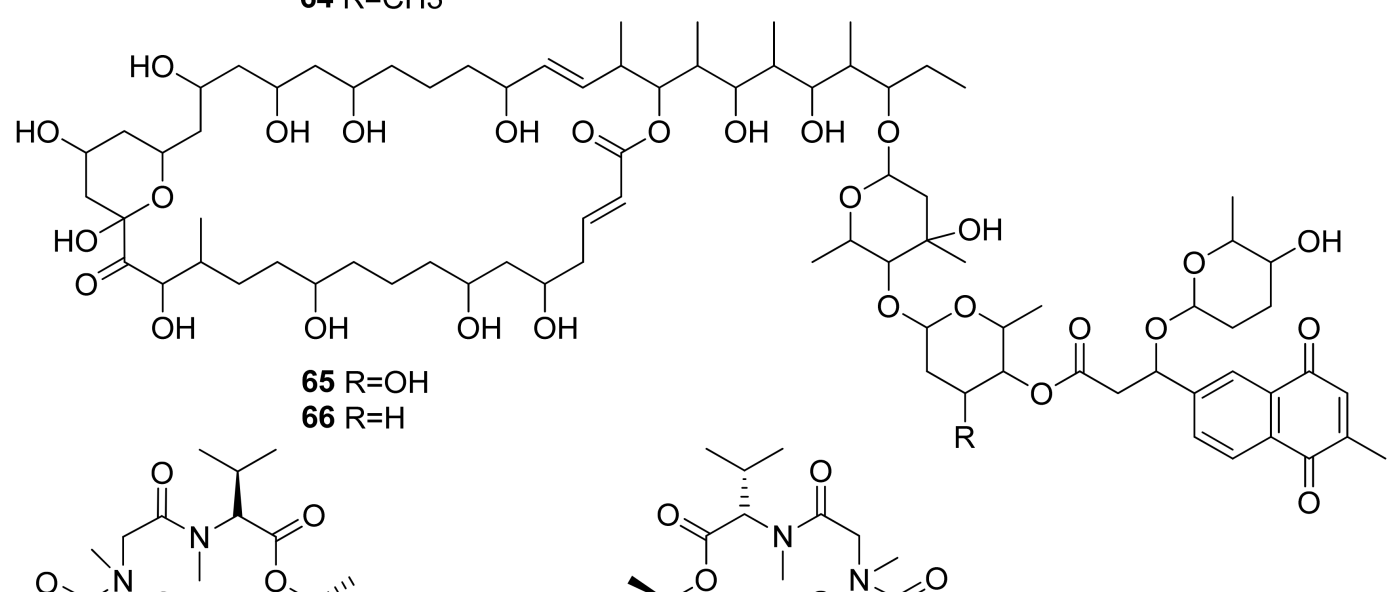

$\mathrm{O}^{\mathrm{N}}$ । $\mathrm{O}^{-. . \prime \prime}$

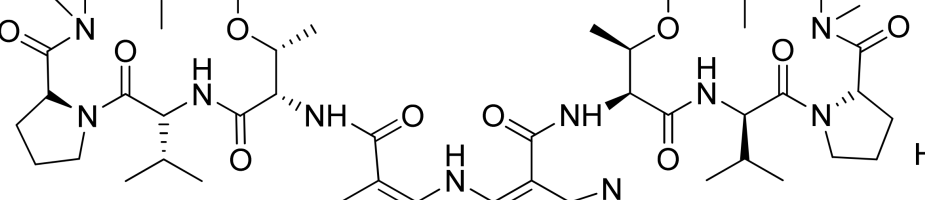<smiles>[R]c1nc2c(C(=O)NCCCC)c3c(c(C)c2o1)Oc1c(C)ccc(C(=O)O)c1N3</smiles><smiles>COc1cccc2[nH]cc(C)c12</smiles>

等

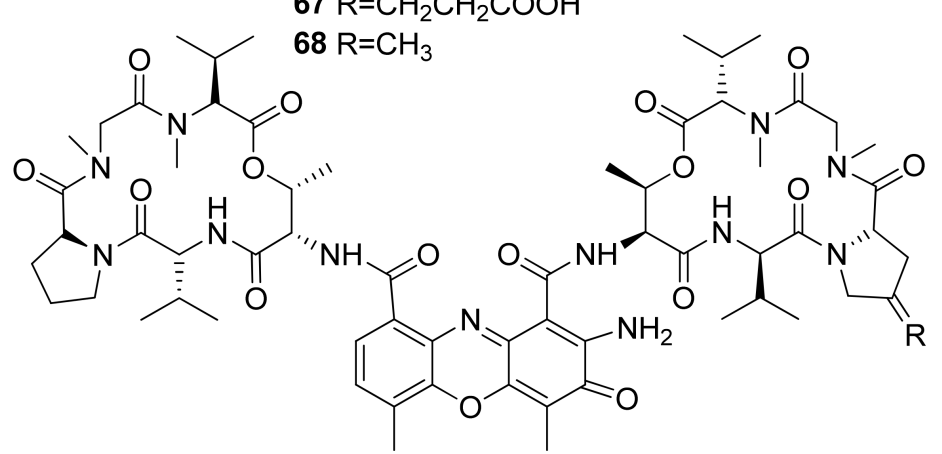<smiles>CNC(C(=O)NC(C(=O)N[C@H](C(=O)N(C)C(C(=O)N[C@H](C(=O)N(C)C(CC(C)C)C(=O)NC(C(=O)N(C)C)C(C)C)C(C)C)C(C)O)C(C)C)C(C)C)C(C)C</smiles>

$69 \mathrm{R}=\mathrm{H}$

$70 \mathrm{R}=\mathrm{O}$

Figure 4. Chemical structures of compounds 63-71. 


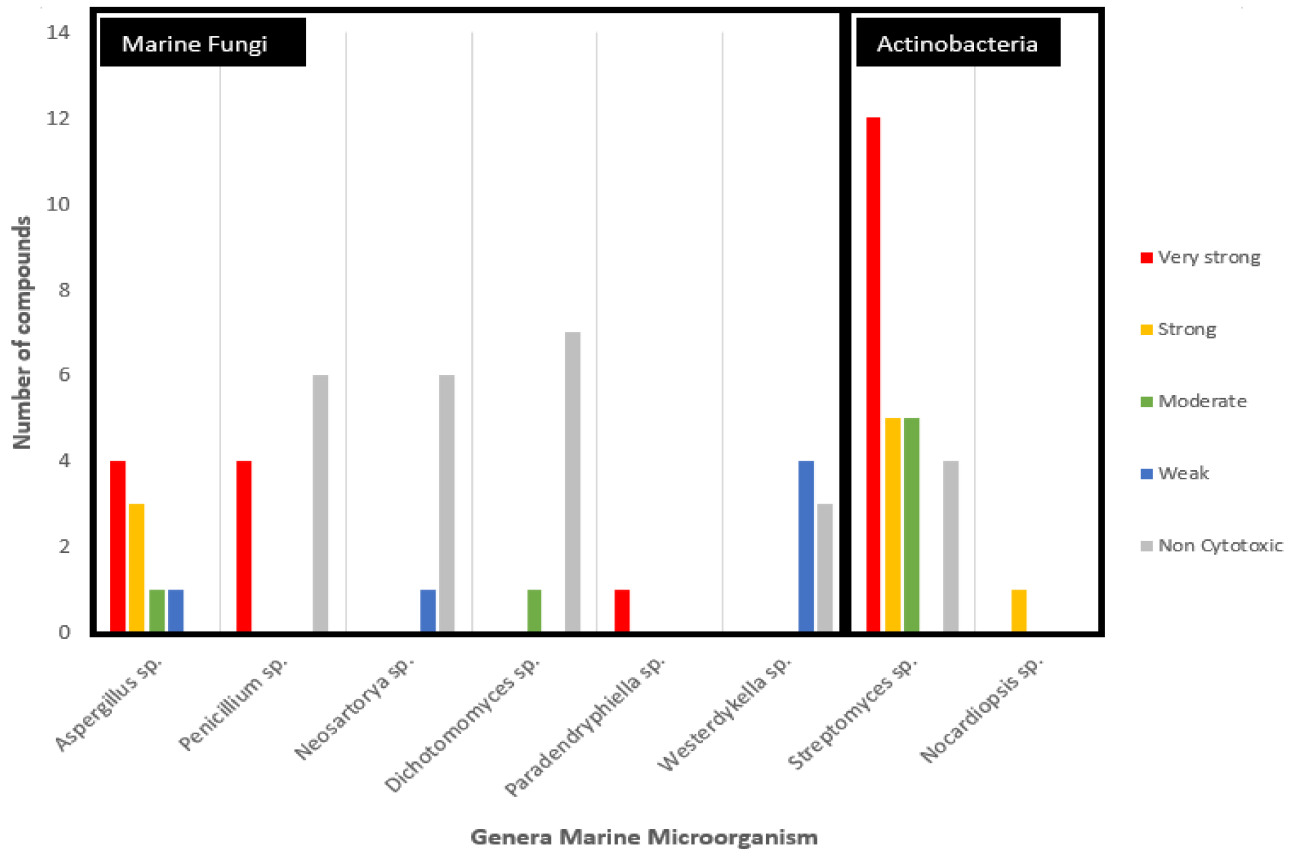

Figure 5. Anticancer potential of secondary metabolites sourced from marine fungi grouped on the basis of the genus of the source microorganism and activity against colorectal cancer cell lines.

\section{Cytotoxicity Assays}

In general, cytotoxicity assays are generally carried out using spectrophotometric method with stains such as 3-[4,5-dimethylthiazol-2-yl]-2,5 diphenyl tetrazolium bromide (MTT), 3-(4,5-dimethylthiazol-2-yl)-5-(3-carboxymethoxyphenyl)-2-(4-sulfophenyl)2H-tetrazolium (MTS), monosodium salt (WST-1), and sulforhodamine B (SRB) [43]. Most of the cytotoxicity assays of metabolites derived from marine fungi are performed comprising of the MTT assay (Table 1), with a few notably highlighted in a few papers utilizing the SRB assay. In contrast, MTS and WST-1 were utilized by only one paper in this review. The MTT assay is preferable to other methods because it arguably has a high reproducibility rate, is sufficiently safe and straightforward to use in laboratory conditions, is highly sensitive for cytotoxicity testing [44], and is suitable for high-throughput screening and miniaturization [45].

MTS is considered an enhanced tetrazolium reagent. In the MTS assay, it is not required to solubilize the precipitate of formazan, hence creating a more straightforward protocol [43]. However, unlike the MTS assay, the MTT assay does not have problems when the absorbance is disturbed by cell type/amounts or incubation time, for example, with the presence of $10 \%$ albumin in a serum sample [46]. WST-1 is also a tetrazolium reagent in a salt form. Therefore, the WST-1 assay produced formazan, which is highly soluble in water. Similar to the MTS assay, the WST-1 assay also does not require solubilization of formazan as in the MTT assay [47]. The WST-1 assay is very sensitive; however, the reagent is much more expensive than the MTT reagent. In addition to that, the WST-1 assay is heavily affected by the interference of manganese particles and carbon nanotubes [47].

Compared with the other two tetrazolium reagents, MTT is considerably more affordable and, hence, more preferable. Regardless of being preferable, the MTT assay has also disadvantages. The results obtained from the MTT assay can be affected by contaminants' interference in reading absorbance values. There is also the need for organic solvents such as dimethyl sulfoxide to solubilize resulting crystals. These disadvantages, in turn, can create false positives and false negatives [48]. Nevertheless, these disadvantages are systematically manageable, for example, with proper training against contaminant interference.

Another colorimetric assay for cancer cell viability shown to be in frequent use, albeit fewer, is the SRB assay. Unlike the MTT assay, the SRB assay does not distinguish between 
viable and dead cells [49]. However, it is also considered a sensitive and rapid method with the principle of the SRB agents binding to amino acid residues in the presence of trichloroacetic acid. It has high reproducibility and linearity and has less likelihood to be affected by environmental factors. The SRB assay is rarely affected by the interference of some compounds. However, multiple washing and drying steps are required. Moreover, homogeneity in tested cancer cell suspensions is necessary [49].

Table 1. Summary of potential cytotoxic metabolites from various marine microorganisms against colorectal cancer.

\begin{tabular}{|c|c|c|c|c|c|}
\hline Compound & Chemical Class & Producing Strain & Method, Cell Lines & Anticancer Potential * & Ref \\
\hline \multicolumn{6}{|c|}{ Marine fungi } \\
\hline Rosellichalasin (1) & $\begin{array}{c}\text { Alkaloid, } \\
\text { Cytochalasins }\end{array}$ & $\begin{array}{l}\text { Aspergillus sp. } \\
\text { nov. F1 }\end{array}$ & MTT assay, RKO & Moderate with $\mathrm{IC}_{50}=37.3 \mu \mathrm{M}$ & [16] \\
\hline Cytochalasin E (2) & $\begin{array}{c}\text { Alkaloid, } \\
\text { Cytochalasins }\end{array}$ & $\begin{array}{l}\text { Aspergillus sp. } \\
\text { nov. F1 }\end{array}$ & MTT assay, RKO & Weak with $\mathrm{IC}_{50}=62.3 \mu \mathrm{M}$ & [16] \\
\hline Allianthrone A (3) & Bianthrone & $\begin{array}{c}\text { A. alliaceus } \\
\text { (new strain, G4) }\end{array}$ & MTT assay, HCT116 & Very strong with $\mathrm{IC}_{50}=9 \mu \mathrm{M}$ & [18] \\
\hline Allianthrone B (4) & Bianthrone & $\begin{array}{c}\text { A. alliaceus } \\
\text { (new strain, G4) }\end{array}$ & MTT assay, HCT117 & Very strong with $\mathrm{IC}_{50}=10.5 \mu \mathrm{M}$ & [18] \\
\hline Allianthrone C (5) & Bianthrone & $\begin{array}{c}\text { A. alliaceus } \\
\text { (new strain, G4) }\end{array}$ & MTT assay, HCT118 & Strong with $\mathrm{IC}_{50}=13.7 \mu \mathrm{M}$ & [18] \\
\hline Fellutamide F (6) & Peptide, Lipopeptide & A. versicolor $\mathrm{PF} 10 \mathrm{M}$ & SRB assay, HCT15 & Strong with $\mathrm{IC}_{50}=0.13 \mu \mathrm{g} / \mathrm{mL}$ & [19] \\
\hline Fellutamide C (7) & Peptide, Lipopeptide & A. versicolor PF10M & SRB assay, HCT15 & Strong with $\mathrm{IC}_{50}=1.74 \mu \mathrm{g} / \mathrm{mL}$ & [19] \\
\hline Asperphenin A (8) & $\begin{array}{c}\text { Peptide, } \\
\text { Lipopeptidyl } \\
\text { Benzophenones } \\
\end{array}$ & A. versicolor $\mathrm{Ppf} 48$ & $S R B$ assay, RKO & Very strong with $\mathrm{IC}_{50}=0.84 \mu \mathrm{M}$ & [22] \\
\hline Asperphenin B (9) & $\begin{array}{c}\text { Peptide, } \\
\text { Lipopeptidyl } \\
\text { Benzophenones }\end{array}$ & A. versicolor Ppf 48 & $S R B$ assay, RKO & Very strong with $\mathrm{IC}_{50}=1.26 \mu \mathrm{M}$ & [22] \\
\hline Penipacid A (10) & $\begin{array}{l}\text { Anthranilic acid } \\
\text { derivatives }\end{array}$ & P. paneum SD-44 & MTT assay, RKO & Very strong with $\mathrm{IC}_{50}=8.4 \mu \mathrm{M}$ & [23] \\
\hline Penipacid B (11) & $\begin{array}{c}\text { Anthranilic acid } \\
\text { derivatives }\end{array}$ & P. paneum SD-44 & MTT assay, RKO & Non-cytotoxic & [23] \\
\hline Penipacid C (12) & $\begin{array}{c}\text { Anthranilic acid } \\
\text { derivatives }\end{array}$ & P. paneum SD-44 & MTT assay, RKO & Non-cytotoxic & [23] \\
\hline Penipacid D (13) & $\begin{array}{c}\text { Anthranilic acid } \\
\text { derivatives }\end{array}$ & P. paneum SD-44 & MTT assay, RKO & Non-cytotoxic & [23] \\
\hline Penipacid E (14) & $\begin{array}{l}\text { Anthranilic acid } \\
\text { derivatives }\end{array}$ & P. paneum SD-44 & MTT assay, RKO & Very strong with $\mathrm{IC}_{50}=9.7 \mu \mathrm{M}$ & [23] \\
\hline Compound (15) & $\begin{array}{c}\text { Anthranilic acid } \\
\text { derivatives }\end{array}$ & P. paneum SD-44 & MTT assay, RKO & Non-cytotoxic & \\
\hline Brocazine A (16) & $\begin{array}{c}\text { Peptide, } \\
\text { Diketopiperazines } \\
\text { with disulfide-bridged }\end{array}$ & P. brocae MA-231 & MTT assay, SW480 & Very strong with $\mathrm{IC}_{50}=2.0 \mathrm{nM}$ & [25] \\
\hline Brocazine B (17) & $\begin{array}{c}\text { Peptide, } \\
\text { Diketopiperazines } \\
\text { with disulfide-bridged }\end{array}$ & P. brocae MA-231 & MTT assay, SW480 & Very strong with $\mathrm{IC}_{50}=1.2 \mathrm{nM}$ & [25] \\
\hline Brocazine C (18) & $\begin{array}{c}\text { Peptide, } \\
\text { Diketopiperazines } \\
\text { with disulfide-bridged }\end{array}$ & P. brocae MA-231 & MTT assay, SW480 & Non-cytotoxic & [25] \\
\hline Brocazine D (19) & $\begin{array}{c}\text { Peptide, } \\
\text { Diketopiperazines } \\
\text { with disulfide-bridged }\end{array}$ & P. brocae MA-231 & MTT assay, SW480 & Non-cytotoxic & [25] \\
\hline Brocazine E (20) & $\begin{array}{c}\text { Peptide, } \\
\text { Diketopiperazines } \\
\text { with disulfide-bridged }\end{array}$ & P. brocae MA-231 & - & $\begin{array}{l}\text { Not tested but showed activity } \\
\text { against Du145, Hela, HepG2, } \\
\text { MCF-7, NCI-H460, SGC-7901, } \\
\text { SW1990, and U251 }\end{array}$ & [25] \\
\hline
\end{tabular}


Table 1. Cont.

\begin{tabular}{|c|c|c|c|c|c|}
\hline Compound & Chemical Class & Producing Strain & Method, Cell Lines & Anticancer Potential * & Ref \\
\hline Brocazine F (21) & $\begin{array}{c}\text { Peptide, } \\
\text { Diketopiperazines } \\
\text { with disulfide-bridged }\end{array}$ & P. brocae MA-231 & - & $\begin{array}{l}\text { Not tested but showed activity } \\
\text { against Du145, Hela, HepG2, } \\
\text { MCF-7, NCI-H460, SGC-7901, } \\
\text { SW1990, and U251 }\end{array}$ & [25] \\
\hline $\begin{array}{c}\text { 18-oxo-19,20- } \\
\text { dihydrophomacin } \\
\text { C (22) }\end{array}$ & $\begin{array}{c}\text { Alkaloid, } \\
\text { Cytochalasans }\end{array}$ & W. dispersa XL602 & MTT assay, HT29 & Non-cytotoxic & [27] \\
\hline $\begin{array}{l}\text { 18-oxo-19-methoxy- } \\
\text { 19,20- } \\
\text { dihydrophomacin C } \\
\text { C (23) }\end{array}$ & $\begin{array}{c}\text { Alkaloid } \\
\text { Cytochalasans }\end{array}$ & W. dispersa XL602 & MTT assay, HT29 & Non-cytotoxic & [27] \\
\hline $\begin{array}{l}\text { 18-oxo-19-hydroxyl- } \\
\text { 19,20- } \\
\text { dihydrophomacin } \\
\text { C (24) }\end{array}$ & $\begin{array}{c}\text { Alkaloid, } \\
\text { Cytochalasans }\end{array}$ & W. dispersa XL602 & MTT assay, HT29 & Non-cytotoxic & [27] \\
\hline $\begin{array}{c}19,20- \\
\text { dihydrophomacin } \\
\text { C (25) }\end{array}$ & $\begin{array}{c}\text { Alkaloid, } \\
\text { Cytochalasans }\end{array}$ & W. dispersa XL602 & MTT assay, HT29 & Weak with $\mathrm{IC}_{50}=49.09 \mu \mathrm{M}$ & [27] \\
\hline $\begin{array}{l}\text { 19-methoxy-19,20- } \\
\text { dihydrophomacin C (26) }\end{array}$ & $\begin{array}{c}\text { Alkaloid, } \\
\text { Cytochalasans }\end{array}$ & W. dispersa XL602 & MTT assay, HT29 & Weak with $\mathrm{IC}_{50}=55.31 \mu \mathrm{M}$ & [27] \\
\hline $\begin{array}{l}\text { 19-hydroxyl-19,20- } \\
\text { dihydrophomacin } \\
\text { C (27) }\end{array}$ & $\begin{array}{c}\text { Alkaloid, } \\
\text { Cytochalasans }\end{array}$ & W. dispersa XL602 & MTT assay, HT29 & Weak with $\mathrm{IC}_{50}=55.48 \mu \mathrm{M}$ & [27] \\
\hline Gymnastatin Z (28) & $\begin{array}{c}\text { Alkaloid, } \\
\text { Tyrosine-derivative }\end{array}$ & W. dispersa XL602 & MTT assay, HT29 & Weak with $\mathrm{IC}_{50}=49.31 \mu \mathrm{M}$ & [27] \\
\hline $\begin{array}{l}(3 \mathrm{R}, 6 \mathrm{R}) \\
\text { Hyalodendrin (29) }\end{array}$ & $\begin{array}{c}\text { Heterocyclic } \\
\text { aromatics, Piperazine }\end{array}$ & P. salina $\mathrm{PC} 362 \mathrm{H}$ & MTT assay, HCT116oxa & Very Strong with $\mathrm{IC}_{50}=25.7 \mathrm{nM}$ & [28] \\
\hline Dichotomocej A (30) & Amides & D. cejpii F31-1 & SRB assay, HCT116 & Non-cytotoxic & [30] \\
\hline Diorcinol (31) & Polyphenols & D. cejpii F31-1 & SRB assay, HCT116 & Non-cytotoxic & [30] \\
\hline $\begin{array}{l}\text { 3-O-methyldiorcinol } \\
\text { (32) }\end{array}$ & Polyphonols & D. cejpii F31-1 & SRB assay, HCT116 & Non-cytotoxic & [30] \\
\hline $\begin{array}{l}\text { Butyl (2-ethylhexyl) } \\
\text { phthalate (33) }\end{array}$ & Phthalic Acid Esters & D. cejpii F31-1 & SRB assay, HCT116 & Non-cytotoxic & [30] \\
\hline Dichocerazine A (34) & Diketopiperazines & D. cejpii F31-1 & SRB assay, HCT116 & Non-cytotoxic & [30] \\
\hline Pityriacitrin (35) & $\begin{array}{l}\text { Alkaloid, } \\
\text { Indoles }\end{array}$ & D. cejpii F31-1 & SRB assay, HCT116 & Moderate with $\mathrm{IC}_{50}=35.1 \mu \mathrm{M}$ & [30] \\
\hline Stellarine A (36) & $\begin{array}{l}\text { Alkaloid, } \\
\text { Indoles }\end{array}$ & D. cejpii F31-1 & SRB assay, HCT116 & Non-cytotoxic & [30] \\
\hline $\begin{array}{l}\text { Indolyl-3-acetic acid } \\
\text { methyl ester (37) }\end{array}$ & $\begin{array}{l}\text { Alkaloid, } \\
\text { Indoles }\end{array}$ & D. cejpii F31-1 & SRB assay, HCT116 & Non-cytotoxic & [30] \\
\hline Chevalone C (38) & Meroterpenoids & $\begin{array}{l}\text { N. siamensis } \\
\text { KUFA } 0017\end{array}$ & MTT assay, HCT116 & $\begin{array}{l}\text { Non-cytotoxic with } \\
\mathrm{IC}_{50}=153 \mu \mathrm{M}\end{array}$ & [31] \\
\hline $\begin{array}{l}\text { Nortryptoquivaline } \\
\text { (39) }\end{array}$ & $\begin{array}{c}\alpha \text {-amino acid } \\
\text { ester derivatives }\end{array}$ & $\begin{array}{l}\text { N. siamensis } \\
\text { KUFA } 0017\end{array}$ & MTT assay, HCT116 & $\begin{array}{l}\text { Non-cytotoxic with } \\
\mathrm{IC}_{50}=114 \mu \mathrm{M}\end{array}$ & [31] \\
\hline $\begin{array}{c}\text { Tryptoquivaline } \\
\text { H (40) }\end{array}$ & $\begin{array}{c}\alpha \text {-amino acid } \\
\text { ester derivatives }\end{array}$ & $\begin{array}{l}\text { N. siamensis } \\
\text { KUFA } 0017\end{array}$ & MTT assay, HCT116 & $\begin{array}{l}\text { Non-cytotoxic with } \\
\mathrm{IC}_{50}=202 \mu \mathrm{M}\end{array}$ & [31] \\
\hline Fiscalin A (41) & $\begin{array}{l}\text { Alkaloid, } \\
\text { Indoles }\end{array}$ & $\begin{array}{l}\text { N. siamensis } \\
\text { KUFA } 0017\end{array}$ & MTT assay, HCT116 & $\begin{array}{l}\text { Non-cytotoxic with } \\
\mathrm{IC}_{50}=123 \mu \mathrm{M}\end{array}$ & [31] \\
\hline epi-Fiscalin A (42) & $\begin{array}{l}\text { Alkaloid, } \\
\text { Indoles }\end{array}$ & $\begin{array}{l}\text { N. siamensis } \\
\text { KUFA } 0017\end{array}$ & MTT assay, HCT116 & $\begin{array}{l}\text { Non-cytotoxic with } \\
\mathrm{IC}_{50}=277 \mu \mathrm{M}\end{array}$ & [31] \\
\hline epi-Neofiscalin A (43) & $\begin{array}{l}\text { Alkaloid, } \\
\text { Indoles }\end{array}$ & $\begin{array}{l}\text { N. siamensis } \\
\text { KUFA } 0017\end{array}$ & MTT assay, HCT116 & $\begin{array}{l}\text { Non-cytotoxic with } \\
\mathrm{IC}_{50}=203 \mu \mathrm{M}\end{array}$ & [31] \\
\hline epi-Fiscalin C (44) & $\begin{array}{l}\text { Alkaloid, } \\
\text { Indoles }\end{array}$ & $\begin{array}{l}\text { N. siamensis } \\
\text { KUFA } 0017\end{array}$ & MTT assay, HCT116 & Weak with $\mathrm{IC}_{50}=86 \mu \mathrm{M}$ & [31] \\
\hline
\end{tabular}


Table 1. Cont.

\begin{tabular}{|c|c|c|c|c|c|}
\hline Compound & Chemical Class & Producing Strain & Method, Cell Lines & Anticancer Potential * & Ref \\
\hline \multicolumn{6}{|c|}{ Actinobacteria } \\
\hline Androsamide (45) & $\begin{array}{l}\text { Peptide, Cyclic } \\
\text { Tetrapeptide }\end{array}$ & $\begin{array}{c}\text { Nocardiopsis sp. } \\
\text { CNT-189 }\end{array}$ & $\begin{array}{c}\text { MTT assay, Caco-2 } \\
\text { and HCT116 }\end{array}$ & $\begin{array}{l}\text { Strong (for both cell lines tested) } \\
\text { with } \mathrm{IC}_{50}=13 \mu \mathrm{M} \text { againts } \\
\text { Caco- } 2 \text { cells and } \mathrm{IC}_{50}=21 \mu \mathrm{M} \\
\text { againts HCT116 cells }\end{array}$ & [32] \\
\hline Cyclo(Pro-Ala) (46) & $\begin{array}{c}\text { Peptide, } \\
\text { Diketopiperazines }\end{array}$ & S. nigra sp. nov. 452 & MTT assay, HCT116 & $\begin{array}{l}\text { Moderate with } \\
\mathrm{IC}_{50}=47.6 \mu \mathrm{g} / \mathrm{mL}\end{array}$ & [33] \\
\hline Cyclo(Pro-Val) (47) & $\begin{array}{c}\text { Peptide, } \\
\text { Diketopiperazines }\end{array}$ & S. nigra sp. nov. 452 & MTT assay, HCT116 & $\begin{array}{l}\text { Moderate with } \\
\mathrm{IC}_{50}=67.2 \mu \mathrm{g} / \mathrm{mL}\end{array}$ & [33] \\
\hline Cyclo(Pro-Leu) (48) & $\begin{array}{c}\text { Peptide, } \\
\text { Diketopiperazines }\end{array}$ & S. nigra sp. nov. 452 & MTT assay, HCT116 & $\begin{array}{l}\text { Moderate with } \\
\mathrm{IC}_{50}=92.6 \mu \mathrm{g} / \mathrm{mL}\end{array}$ & [33] \\
\hline Cyclo(Pro-Phe) (49) & $\begin{array}{c}\text { Peptide, } \\
\text { Diketopiperazines }\end{array}$ & S. nigra sp. nov. 452 & MTT assay, HCT116 & $\begin{array}{l}\text { Moderate with } \\
\mathrm{IC}_{50}=32.3 \mu \mathrm{g} / \mathrm{mL}\end{array}$ & [33] \\
\hline $\begin{array}{c}\text { Furan-type } \\
\text { Compound (50) }\end{array}$ & $\begin{array}{c}\text { Heterocyclic } \\
\text { aromatics, Furan }\end{array}$ & Streptomyces sp. VN1 & MTT assay, HCT116 & $\begin{array}{l}\text { Non-cytotoxic with } \\
\mathrm{IC}_{50}=123.7 \mu \mathrm{M}\end{array}$ & [34] \\
\hline Petrocidin A (51) & $\begin{array}{l}\text { Peptide, Cyclic } \\
\text { Dipeptide }\end{array}$ & $\begin{array}{c}\text { Streptomyces sp. } \\
\text { SBT348 }\end{array}$ & MTT assay, HT29 & Strong with $\mathrm{IC}_{50}=5.3 \mu \mathrm{g} / \mathrm{mL}$ & [35] \\
\hline $\begin{array}{c}2,3- \\
\text { dihydroxybenzoic } \\
\text { acid (52) }\end{array}$ & Benzene & $\begin{array}{l}\text { Streptomyces sp. } \\
\text { SBT348 }\end{array}$ & MTT assay, HT29 & Non-cytotoxic & \\
\hline $\begin{array}{c}2,3- \\
\text { Dihydroxybenzamide } \\
(\mathbf{5 3})\end{array}$ & Benzene & $\begin{array}{l}\text { Streptomyces sp. } \\
\text { SBT348 }\end{array}$ & MTT assay, HT29 & Strong with $\mathrm{IC}_{50}=3.8 \mu \mathrm{g} / \mathrm{mL}$ & [35] \\
\hline Maltol (54) & $4 H$-pyran & $\begin{array}{l}\text { Streptomyces sp. } \\
\text { SBT348 }\end{array}$ & MTT assay, HT29 & Non-cytotoxic & \\
\hline $\begin{array}{l}\text { Napyradiomycin } \\
\text { CNQ525.510B (55) }\end{array}$ & $\begin{array}{c}\text { Terpene, } \\
\text { Meroterpenoids }\end{array}$ & $\begin{array}{l}\text { Streptomyces sp. } \\
\text { CNQ525 }\end{array}$ & MTS assay, HCT116 & Strong with $\mathrm{IC}_{50}=17 \mu \mathrm{M}$ & [37] \\
\hline $\begin{array}{l}\text { Napyradiomycin } \\
\text { CNQ525.538 (56) }\end{array}$ & $\begin{array}{c}\text { Terpene, } \\
\text { Meroterpenoids }\end{array}$ & $\begin{array}{l}\text { Streptomyces sp. } \\
\text { CNQ525 }\end{array}$ & MTS assay, HCT116 & Very strong with $\mathrm{IC}_{50}=6 \mu \mathrm{M}$ & [37] \\
\hline $\begin{array}{l}\text { Napyradiomycin } \\
\text { CNQ525.554 (57) }\end{array}$ & $\begin{array}{c}\text { Terpene, } \\
\text { Meroterpenoids }\end{array}$ & $\begin{array}{l}\text { Streptomyces sp. } \\
\text { CNQ525 }\end{array}$ & MTS assay, HCT116 & Non-cytotoxic & \\
\hline $\begin{array}{l}\text { Napyradiomycin } \\
\text { CNQ525.600 (58) }\end{array}$ & $\begin{array}{c}\text { Terpene, } \\
\text { Meroterpenoids }\end{array}$ & $\begin{array}{l}\text { Streptomyces sp. } \\
\text { CNQ525 }\end{array}$ & MTS assay, HCT116 & Moderate with $\mathrm{IC}_{50}=49 \mu \mathrm{M}$ & [37] \\
\hline Dionemycin (59) & Alkaloid, Indoles & $\begin{array}{l}\text { Streptomyces strain } \\
\text { SCSIO } 11791\end{array}$ & MTT assay, HCT116 & Very strong with $\mathrm{IC}_{50}=4.3 \mu \mathrm{M}$ & [38] \\
\hline $\begin{array}{l}\text { 6-OMe-7', } 7^{\prime \prime}- \\
\text { dichorochromopyrrolic } \\
\text { acid }(60)\end{array}$ & Alkaloid, Indoles & $\begin{array}{l}\text { Streptomyces strain } \\
\text { SCSIO } 11791\end{array}$ & MTT assay, HCT116 & $\begin{array}{l}\text { Strong againts with } \\
\mathrm{IC}_{50}=13.1 \mu \mathrm{M}\end{array}$ & [38] \\
\hline Lynamicin B (61) & Alkaloid, Indoles & $\begin{array}{l}\text { Streptomyces strain } \\
\text { SCSIO } 11791\end{array}$ & MTT assay, HCT116 & Very strong with $\mathrm{IC}_{50}=8.7 \mu \mathrm{M}$ & [38] \\
\hline Spiroindimicin B (62) & Alkaloid, Indoles & $\begin{array}{l}\text { Streptomyces strain } \\
\text { SCSIO } 11791\end{array}$ & MTT assay, HCT116 & Very strong with $\mathrm{IC}_{50}=2.2 \mu \mathrm{M}$ & [38] \\
\hline K41 A (63) & Polyether & S. cacaoi 14CM034 & WST-1 assay, Caco-2 & Very Strong with $\mathrm{IC}_{50}=7.4 \mu \mathrm{M}$ & [39] \\
\hline Compound (64) & Polyether & S. cacaoi $14 \mathrm{CM} 034$ & WST-1 assay, Caco-2 & Strong with $\mathrm{IC}_{50}=7.4 \mu \mathrm{M}$ & \\
\hline PM100117 (65) & $\begin{array}{c}\text { Macrolide, } \\
\text { Polyhydroxyl }\end{array}$ & $\begin{array}{c}\text { S. caniferus } \\
\text { GUA-06-05-006A }\end{array}$ & SRB assay, HT29 & Very Strong with $\mathrm{LC}_{50}=3.8 \mu \mathrm{M}$ & [40] \\
\hline PM100118 (66) & $\begin{array}{c}\text { Macrolide, } \\
\text { Polyhydroxyl }\end{array}$ & $\begin{array}{l}\text { S. caniferus } \\
\text { GUA-06-05-006A }\end{array}$ & SRB assay, HT29 & Very Strong with $\mathrm{IC}_{50}=4.1 \mu \mathrm{M}$ & [40] \\
\hline $\begin{array}{l}\text { Neo-actinomycin } \\
\text { A (67) }\end{array}$ & $\begin{array}{l}\text { Peptide, Cyclic } \\
\text { Dipeptide }\end{array}$ & $\begin{array}{l}\text { Streptomyces sp. } \\
\text { IMB094 }\end{array}$ & SRB assay, HCT116 & Very Strong with $\mathrm{IC}_{50}=38.7 \mathrm{nM}$ & {$[41]$} \\
\hline $\begin{array}{l}\text { Neo-actinomycin } \\
\text { B (68) }\end{array}$ & $\begin{array}{l}\text { Peptide, Cyclic } \\
\text { Dipeptide }\end{array}$ & $\begin{array}{l}\text { Streptomyces sp. } \\
\text { IMB094 }\end{array}$ & SRB assay, HCT116 & $\begin{array}{l}\text { Very Strong with } \\
\mathrm{IC}_{50}=339.1 \mathrm{nM}\end{array}$ & {$[41]$} \\
\hline Actinomycin D (69) & $\begin{array}{l}\text { Peptide, Cyclic } \\
\text { Dipeptide }\end{array}$ & $\begin{array}{l}\text { Streptomyces sp. } \\
\text { IMB094 }\end{array}$ & SRB assay, HCT116 & $\begin{array}{l}\text { Very Strong with } \\
\mathrm{IC}_{50}=0.045 \mathrm{nM}\end{array}$ & {$[41]$} \\
\hline
\end{tabular}


Table 1. Cont.

\begin{tabular}{|c|c|c|c|c|c|}
\hline Compound & Chemical Class & Producing Strain & Method, Cell Lines & Anticancer Potential * & Ref \\
\hline Actinomycin $X_{2}$ (70) & $\begin{array}{l}\text { Peptide, Cyclic } \\
\text { Dipeptide }\end{array}$ & $\begin{array}{l}\text { Streptomyces sp. } \\
\text { IMB094 }\end{array}$ & SRB assay, HCT116 & $\begin{array}{l}\text { Very Strong with } \\
\mathrm{IC}_{50}=0.0075 \mathrm{nM}\end{array}$ & [41] \\
\hline $\begin{array}{c}\text { Ohmyungsamycin } \\
\text { A (71) }\end{array}$ & $\begin{array}{l}\text { Peptide, Cyclic } \\
\text { Dipeptide }\end{array}$ & $\begin{array}{c}\text { Streptomyces strain } \\
\text { SNJ042 }\end{array}$ & SRB assay, HCT116 & Very Strong with $\mathrm{IC}_{50}=7.61 \mu \mathrm{M}$ & [42] \\
\hline & $\begin{array}{l}{ }^{*} \mathrm{IC}_{50} \mathrm{va} \\
\text { cytotoxic } \\
\text { defined } \\
\text { weak cyt }\end{array}$ & $\begin{array}{l}\mu \mathrm{g} / \mathrm{mL} \text { are }<21 \mu \mathrm{g} \\
\text { th values }>501 \mu \mathrm{g} / \mathrm{r} \\
\text { strong, } 11-25 \mu \mathrm{M} \\
\text { Values above } 100\end{array}$ & $\begin{array}{l}\text { or strong, 21-200 } \mu \mathrm{g} \\
\text { hon-cytotoxic [50]. IC5 } \\
d \text { as strong, 26-50 } \mu \mathrm{M} \\
\text { considered non-cytot }\end{array}$ & $\begin{array}{l}\text { for moderate, and } 201-500 \mu \mathrm{g} / \mathrm{m} \\
\text { easurements in } \mu \mathrm{M} \text {, values of } 1-10 \\
\text { ined as moderate, and } 51-100 \mu \mathrm{N} \\
\text { [51]. }\end{array}$ & $\begin{array}{l}\text { Or w } \\
\text { M car } \\
\text { fined }\end{array}$ \\
\hline
\end{tabular}

\section{Perspectives}

The analyzed anticancer potential compounds are clustered in eight different genera (Figure 5). Larger groupings of the potential marine fungi are observed to belong to Aspergillus sp. and Penicillium sp., albeit these two genera are shown to be promising in terms of the potency of their compounds, with an equal number (four) of metabolites with very strong potency. Particularly, compound (29) isolated from the sole Paradendryphiella $\mathrm{sp}$. is considered very strong based on the rules of anticancer potency classification for CRC, as shown in Table 1. Furthermore, it showed high cytotoxic against MCF7-Sh-WISP2 compared with MCF7 or 3T3-F442A [28]. It is a epipolythiodiketopiperazine (ETP) alkaloid and has been known for its anti-fungal and antibacterial activities [52]. This compound was also isolated from marine fungi Penicillium turbatum and the Hyalodendron sp [53]. Meanwhile, secondary metabolites isolated from Streptomyces sp. show the most potent metabolites from actinobacteria.

The secondary metabolites could be grouped on the basis of their chemical classifications and similarity. In the principle of its basic structure, an indole comprises a benzene ring combined with a pyrrole. This compound and its derivatives have been explored for many pharmacological effects, such as celiac disease, irritable bowel syndrome, and Crohn's disease (National Center for Biotechnology Information, n.d.). The cytotoxic effects of some of its derivatives can be correlated with the halogenation of surrounding functional groups $[38,54]$. Moreover, the presence of a chlorine atom-based functional group shows increasing anticancer potency of an indole-based agent. This is explained by the increased cellular suppression of AKT1 kinase, a well-known cell viability intermediator in P13K pathways of colon cancer and other cancers due to the addition of the 3-chloroacetyl group [55].

In another research, the addition of a (3-chloro-2-nitrobenzene)sulfonyl group on an indole-based scaffold compound exhibited a 100-times increment in its potency against cancer cells. This is related to its apoptotic effects, which is similar to the effects by allosteric regulation while also augmenting the stability of the agent [56]. The significant suppression of cancer cell viability is correlated with the presence of chlorine atoms on the C-6" and shown by compounds $\mathbf{5 9}$ and $\mathbf{6 1}$ isolated from Streptomyces strain SCSIO 11791. These two compounds showed cytotoxicity against MDA-MB-231 human breast adenocarcinoma cells, NCI-H460 human non-small-cell lung cancer cells, HCT-116 colon cancer cells, HepG2 liver cancer cells, and the non-cancerous MCF10A human breast epithelial cells. Moreover, compounds $\mathbf{5 9}$ and $\mathbf{6 1}$ revealed antibacterial activity against Gram-positive bacteria including Micrococcus luteus ML01, Staphylococcus aureus ATCC 29213, and a panel of MRSA isolated from human patients (i.e., MRSA 991, MRSA 1862, MRSA 669 A, and MRSA A2) and pigs (MRSA GDQ6P012P and MRSA GDE4P037P) and against Gram-negative bacteria including Acinetobacter baumannii ATCC 19606, Vibrio coralliilyticus ATCC BAA-450, and Vibrio alginolyticus XSBZ14 [38]. A previous study by McArthur et al., demonstrated that compound $\mathbf{6 1}$ isolated from a marine actinomycete namely Marinispora sp. showed active against drug-resistant pathogens such as methicillinresistant Staphylococcus aureus and Enterococcus faecium [57]. This finding may prove using 
SAR studies that the chlorine atom at C-6 could be pivotal for biological activities in drug design.

This study noted that the effects of cyclic peptides are very interrelated with various apoptotic markers. Importantly, these are specific to the type and extent of derivatization of the cyclic peptides. The development and optimization of cyclic peptides structures as the basis of drug discovery is essential to aim for higher success of target inhibition ensured by more cyclic peptide hits [58]. For instances, actinomycin D (69) is previously well known to possess broad-spectrum antibiotic activities. In a clinical study, it was used as an anticancer drug to treat many tumors, such as Wilms and Ewing tumors, testicular cancer, sarcomas, and choriocarcinoma [59]. In a recent study by Wang et al., comparative anticancer activities of actinomycin D (69) and Neo-actinomycins A (67) indicated the main activity of $5 \mathrm{H}$-oxazolo[4,5-b]phenoxazine chromophore. The results showed 800 -fold reduction in cytotoxic activity relative to 69 against HCT-116 and A549 cancer cells. This could be explained by the activity of the $5 \mathrm{H}$-oxazolo[4,5-b]phenoxazine part of compound 67 on the cytosine subunits of HCT-116 and A-549 cancer cells' DNA [41].

The use of therapeutic peptides can be preferable for CRC treatment. This is related to their potential characteristics such as higher specificity, lower toxicity, and fewer side effects [60]. Nevertheless, their potential use still faces several limitation regarding their instability against metabolism, poor permeability, solubility, and bioavailability. The more advance research and development are required in order to improve their characteristics, especially on the structure-activity relationship.

\section{Conclusions}

There are 71 secondary metabolites isolated from marine fungi and actinobacteria reviewed in this study, which are summarized as around 44 and 27 metabolites, respectively. The fungi are represented by genera Aspergillus sp., Penicillium sp., Neosartorya sp., Dichotomomyces sp., Paradendryphiella sp., and Westerdykella sp. In contrast, the actinobacteria are represented by genera Streptomyces sp. and Nocardiopsis sp. Secondary metabolites from marine microorganisms show potential cytotoxic agents on CRC, particularly those sourced from the fungi of Aspergillus sp., Penicillium sp., and Paradendryphiella sp. and from the actinobacteria Streptomyces sp. Most of the compounds are found to be indole alkaloids and diketopiperazines (Table 1). The peptides and alkaloids from 71 secondary metabolites are the groups with the most potential for the novelty related to cytotoxic activity. Specifically, these are diketopiperazines (cyclic peptide) for peptides and indoles for alkaloids. Their high potency can be explicated as the effects of the introduction of halogen-based functional groups in indole alkaloids and the presence of sulfide groups in diketopiperazines. It is expected that this provide more insight into accelerating drug discovery research and development, particularly with a focus on CRC drugs and marine microbiology.

Author Contributions: All authors contributed equally to the study's conception and design. The material preparation and conceptualization of the idea and analysis were performed by E.J., I.A.A., M.S.W. and M.Y.P. Data from the literature were collected by E.J., I.A.A., M.S.W., M.A., N.T., F.I., A.B.J., A.B., S.I.R. and M.Y.P. The first draft was written I.A.A. and N.T. All authors have read and agreed to the published version of the manuscript.

Funding: This research was funded by the Indonesian Institute of Sciences through DIPA 2021 Research Fund B-10405/IPH/HK.01.03/XI/2020 and partially supported by World Class Research grants 2021; Directorate of Research and Community Engagement; The Ministry of Research, Technology, and Higher Education; the Republic of Indonesia.

Institutional Review Board Statement: Not applicable.

Informed Consent Statement: Not applicable.

Acknowledgments: The authors thank EnagoTM English Editing Service for editing a draft of this manuscript.

Conflicts of Interest: The authors declare no conflict of interest. 


\section{References}

1. Rawla, P.; Sunkara, T.; Barsouk, A. Epidemiology of Colorectal Cancer: Incidence, Mortality, Survival, and Risk Factors. Prz. Gastroenterol. 2019, 14, 89-103. [CrossRef]

2. Van der Jeught, K.; Xu, H.C.; Li, Y.J.; Lu, X.B.; Ji, G. Drug Resistance and New Therapies in Colorectal Cancer. World J. Gastroenterol. 2018, 24, 3834-3848. [CrossRef] [PubMed]

3. Goka, E.T.; Chaturvedi, P.; Lopez, D.T.M.; Garza, A.D.L.; Lippman, M.E. RAC1b Overexpression Confers Resistance to Chemotherapy Treatment in Colorectal Cancer. Mol. Cancer Ther. 2019, 18, 957-968. [CrossRef] [PubMed]

4. Guren, M.G. The Global Challenge of Colorectal Cancer. Lancet Gastroenterol. Hepatol. 2019, 4, 894-895. [CrossRef]

5. Fujita, K.I.; Kubota, Y.; Ishida, H.; Sasaki, Y. Irinotecan, a Key Chemotherapeutic Drug for Metastatic Colorectal Cancer. World J. Gastroenterol. 2015, 12234-12248. [CrossRef] [PubMed]

6. Conti, J.A.; Kemeny, N.E.; Saltz, L.B.; Huang, Y.; Tong, W.P.; Chou, T.C.; Sun, M.; Pulliam, S.; Gonzalez, C. Irinotecan Is an Active Agent in Untreated Patients with Metastatic Colorectal Cancer. J. Clin. Oncol. 1996, 14, 709-715. [CrossRef] [PubMed]

7. Rougier, P.; Bugat, R.; Douillard, J.Y.; Culine, S.; Suc, E.; Brunet, P.; Becouarn, Y.; Ychou, M.; Marty, M.; Extra, J.M.; et al. Phase II Study of Irinotecan in the Treatment of Advanced Colorectal Cancer in Chemotherapy-Naive Patients and Patients Pretreated with Fluorouracil-Based Chemotherapy. J. Clin. Oncol. 2016, 15, 251-260. [CrossRef] [PubMed]

8. Wang, W.; Guo, W.; Li, L.; Fu, Z.; Liu, W.; Gao, J.; Shu, Y.; Xu, Q.; Sun, Y.; Gu, Y. Andrographolide Reversed 5-FU Resistance in Human Colorectal Cancer by Elevating BAX Expression. Biochem. Pharmacol. 2016, 121, 8-17. [CrossRef]

9. Watson, J.L.; Hill, R.; Lee, P.W.; Giacomantonio, C.A.; Hoskin, D.W. Curcumin Induces Apoptosis in HCT-116 Human Colon Cancer Cells in a P21-Independent Manner. Exp. Mol. Pathol. 2008, 84, 230-233. [CrossRef]

10. Su, C.C.; Lin, J.G.; Li, T.M.; Chung, J.G.; Yang, J.S.; Ip, S.W.; Lin, W.C.; Chen, G.W. Curcumin-induced apoptosis of human colon cancer colo 205 cells through the production of ROS, $\mathrm{Ca}^{2+}$ and the activation of caspase-3. Anticancer Res. 2006, 26, 4379-4389. [PubMed]

11. Kim, E.J.; Park, S.Y.; Lee, J.Y.; Park, J.H.Y. Fucoidan Present in Brown Algae Induces Apoptosis of Human Colon Cancer Cells. BMC Gastroenterol. 2010, 10, 1-11. [CrossRef]

12. Tsai, H.L.; Tai, C.J.; Huang, C.W.; Chang, F.R.; Wang, J.Y. Efficacy of Low-Molecular-Weight Fucoidan as a Supplemental Therapy in Metastatic Colorectal Cancer Patients: A Double-Blind Randomized Controlled Trial. Mar. Drugs 2017, 15, 122. [CrossRef]

13. Science, A.I. of M. Australian Institute of Marine Science: Marine Microbes. Available online: https://www.aims.gov.au/docs/ research/marine-microbes/microbes/microbes.html (accessed on 16 February 2021).

14. Salazar, G.; Sunagawa, S. Marine Microbial Diversity. Curr. Biol. 2017, 27, R489-R494. [CrossRef]

15. Committee on the Ocean's Role in Human Health; National Research Council. From Monsoons to Microbes: Understanding the Ocean's Role in Human Health; National Academies Press: Washington, DC, USA, 1999. [CrossRef]

16. Xiao, L.; Liu, H.; Wu, N.; Liu, M.; Wei, J.; Zhang, Y.; Lin, X. Characterization of the High Cytochalasin E and Rosellichalasin Producing-Aspergillus Sp. Nov. F1 Isolated from Marine Solar Saltern in China. World J. Microbiol. Biotechnol. 2013, $29,11-17$. [CrossRef]

17. Haidle, A.M.; Myers, A.G. An enantioselective, modular, and general route to the cytochalasins: Synthesis of L-696,474 and cytochalasin B. Proc. Natl. Acad. Sci. USA 2004, 101, 12048-12053. [CrossRef]

18. Mandelare, P.E.; Adpressa, D.A.; Kaweesa, E.N.; Zakharov, L.N.; Loesgen, S. Coculture of Two Developmental Stages of a Marine-Derived Aspergillus alliaceus Results in the Production of the Cytotoxic Bianthrone Allianthrone A. J. Nat. Prod. 2018, 81, 1014-1022. [CrossRef]

19. Lee, Y.M.; Dang, H.T.; Li, J.; Zhang, P.; Hong, J.; Lee, C.O.; Jung, J.H. A Cytotoxic Fellutamide Analogue from the Sponge-Derived Fungus Aspergillus versicolor. Bull. Korean Chem. Soc. 2011, 32, 3817-3820. [CrossRef]

20. Giltrap, A.M.; Cergol, K.M.; Pang, A.; Britton, W.J.; Payne, R.J. Total Synthesis of Fellutamide B and Deoxy-Fellutamides B, C, and D. Mar. Drugs 2013, 11, 2382-2397. [CrossRef]

21. Hines, J.; Groll, M.; Fahnestock, M.; Crews, C.M. Proteasome Inhibition by Fellutamide B Induces Nerve Growth Factor Synthesis. Chem. Biol. 2008, 15, 501. [CrossRef]

22. Bae, S.Y.; Liao, L.; Park, S.H.; Kim, W.K.; Shin, J.; Lee, S.K. Antitumor Activity of Asperphenin A, a Lipopeptidyl Benzophenone from Marine-Derived Aspergillus Sp. Fungus, by Inhibiting Tubulin Polymerization in Colon Cancer Cells. Mar. Drugs 2020, 18, 110. [CrossRef]

23. Li, C.-S.; Li, X.-M.; Gao, S.-S.; Lu, Y.-H.; Wang, B.-G. Cytotoxic Anthranilic Acid Derivatives from Deep Sea Sediment-Derived Fungus Penicillium Paneum SD-44. Mar. Drugs 2013, 11, 3068-3076. [CrossRef] [PubMed]

24. Congiu, C.; Cocco, M.T.; Lilliu, V.; Onnis, V. New Potential Anticancer Agents Based on the Anthranilic Acid Scaffold: Synthesis and Evaluation of Biological Activity. J. Med. Chem. 2005, 48, 8245-8252. [CrossRef] [PubMed]

25. Meng, L.H.; Li, X.M.; Lv, C.T.; Huang, C.G.; Wang, B.G. Brocazines A-F, Cytotoxic Bisthiodiketopiperazine Derivatives from Penicillium Brocae MA-231, an Endophytic Fungus Derived from the Marine Mangrove Plant Avicennia Marina. J. Nat. Prod. 2014, 77, 1921-1927. [CrossRef] [PubMed]

26. Choi, E.J.; Park, J.S.; Kim, Y.J.; Jung, J.H.; Lee, J.K.; Kwon, H.C.; Yang, H.O. Apoptosis-Inducing Effect of Diketopiperazine Disulfides Produced by Aspergillus Sp. KMD 901 Isolated from Marine Sediment on HCT116 Colon Cancer Cell Lines. J. Appl. Microbiol. 2011, 110, 304-313. [CrossRef] 
27. Xu, D.; Luo, M.; Liu, F.; Wang, D.; Pang, X.; Zhao, T.; Xu, L.; Wu, X.; Xia, M.; Yang, X. Cytochalasan and Tyrosine-Derived Alkaloids from the Marine Sediment-Derived Fungus Westerdykella Dispersa and Their Bioactivities. Sci. Rep. 2017, 7, 1-9. [CrossRef]

28. Dezaire, A.; Marchand, C.H.; Vallet, M.; Ferrand, N.; Chaouch, S.; Mouray, E.; Larsen, A.K.; Sabbah, M.; Lemaire, S.D.; Prado, S.; et al. Secondary Metabolites from the Culture of the Marine-Derived Fungus Paradendryphiella Salina PC 362H and Evaluation of the Anticancer Activity of Its Metabolite Hyalodendrin. Mar. Drugs 2020, 18, 191. [CrossRef]

29. Welch, T.R.; Williams, R.M. Epidithiodioxopiperazines. occurrence, synthesis and biogenesis. Nat. Prod. Rep. 2014, 31, 1376-1404. [CrossRef]

30. Chen, Y.X.; Xu, M.Y.; Li, H.J.; Zeng, K.J.; Ma, W.Z.; Tian, G.B.; Xu, J.; Yang, D.P.; Lan, W.J. Diverse Secondary Metabolites from the Marine-Derived Fungus Dichotomomyces Cejpii F31-1. Mar. Drugs 2017, 15, 339. [CrossRef]

31. Ramos, A.A.; Buttachon, S.; Marques, P.; Dethoup, T.; Kijjoa, A.; Rocha, E. Cytotoxic Activity of Secondary Metabolites from Marine-Derived Fungus Neosartorya Siamensis in Human Cancer Cells. Phyther. Res. 2016, 30, 1862-1871.

32. Lee, J.; Gamage, C.D.B.; Kim, G.J.; Hillman, P.F.; Lee, C.; Lee, E.Y.; Choi, H.; Kim, H.; Nam, S.J.; Fenical, W. Androsamide, a Cyclic Tetrapeptide from a Marine Nocardiopsis sp., Suppresses Motility of Colorectal Cancer Cells. J. Nat. Prod. 2020, 83, 3166-3172. [CrossRef]

33. Chen, C.; Ye, Y.; Wang, R.; Zhang, Y.; Wu, C.; Debnath, S.C.; Ma, Z.; Wang, J.; Wu, M. Streptomyces Nigra Sp. Nov. Is a Novel Actinobacterium Isolated from Mangrove Soil and Exerts a Potent Antitumor Activity in vitro. Front. Microbiol. $2018,9,1587$. [CrossRef]

34. Nguyen, H.T.; Pokhrel, A.R.; Nguyen, C.T.; Pham, V.T.T.; Dhakal, D.; Lim, H.N.; Jung, H.J.; Kim, T.S.; Yamaguchi, T.; Sohng, J.K. Streptomyces Sp. VN1, a Producer of Diverse Metabolites Including Non-Natural Furan-Type Anticancer Compound. Sci. Rep. 2020, 10, 1756. [CrossRef]

35. Cheng, C.; Othman, E.M.; Stopper, H.; Edrada-Ebel, R.A.; Hentschel, U.; Abdelmohsen, U.R. Isolation of Petrocidin a, a New Cytotoxic Cyclic Dipeptide from the Marine Sponge-Derived Bacterium Streptomyces sp. SBT348. Mar. Drugs 2017, 15, 383. [CrossRef]

36. Jinendiran, S.; Teng, W.; Dahms, H.U.; Liu, W.; Ponnusamy, V.K.; Chiu, C.C.C.; Kumar, B.S.D.; Sivakumar, N. Induction of Mitochondria-Mediated Apoptosis and Suppression of Tumor Growth in Zebrafish Xenograft Model by Cyclic Dipeptides Identified from Exiguobacterium acetylicum. Sci. Rep. 2020, 10, 13721. [CrossRef]

37. Farnaes, L.; Coufal, N.G.; Kauffman, C.A.; Rheingold, A.L.; Dipasquale, A.G.; Jensen, P.R.; Fenical, W. Napyradiomycin Derivatives, Produced by a Marine-Derived Actinomycete, Illustrate Cytotoxicity by Induction of Apoptosis. J. Nat. Prod. 2014, 77, 15-21. [CrossRef]

38. Song, Y.; Yang, J.; Yu, J.; Li, J.; Yuan, J.; Wong, N.K.; Ju, J. Chlorinated Bis-Indole Alkaloids from Deep-Sea Derived Streptomyces Sp. SCSIO 11791 with Antibacterial and Cytotoxic Activities. J. Antibiot. 2020, 73, 542-547. [CrossRef]

39. Khan, N.; Yılmaz, S.; Aksoy, S.; Uzel, A.; Tosun, Ç.; Kirmizibayrak, P.B.; Bedir, E. Polyethers Isolated from the Marine Actinobacterium Streptomyces Cacaoi Inhibit Autophagy and Induce Apoptosis in Cancer Cells. Chem. Biol. Interact. 2019, 307, 167-178. [CrossRef]

40. Pérez, M.; Schleissner, C.; Fernández, R.; Rodríguez, P.; Reyes, F.; Zuñiga, P.; De La Calle, F.; Cuevas, C. PM100117 and PM100118, New Antitumor Macrolides Produced by a Marine Streptomyces Caniferus GUA-06-05-006A. J. Antibiot. 2016, 69, 388-394. [CrossRef]

41. Wang, Q.; Zhang, Y.; Wang, M.; Tan, Y.; Hu, X.; He, H.; Xiao, C.; You, X.; Wang, Y.; Gan, M. Neo-Actinomycins A and B, Natural Actinomycins Bearing the 5H-Oxazolo[4,5-b]Phenoxazine Chromophore, from the Marine-Derived Streptomyces Sp. IMB094. Sci. Rep. 2017, 7, 3591. [CrossRef]

42. Byun, W.S.; Kim, S.; Shin, Y.H.; Kim, W.K.; Oh, D.C.; Lee, S.K. Antitumor Activity of Ohmyungsamycin A through the Regulation of the Skp2-P27 Axis and MCM4 in Human Colorectal Cancer Cells. J. Nat. Prod. 2020, 83, 118-126. [CrossRef]

43. Kamiloglu, S.; Sari, G.; Ozdal, T.; Capanoglu, E. Guidelines for Cell Viability Assays. Food Front. 2020, 1, 332-349. [CrossRef]

44. Van Tonder, A.; Joubert, A.M.; Cromarty, A.D. Limitations of the 3-(4,5-dimethylthiazol-2-yl)-2,5-diphenyl-2H-tetrazolium bromide (MTT) assay when compared to three commonly used cell enumeration assays. BMC Res. Notes. 2015, 8, 47. [CrossRef]

45. Hamid, R.; Rotshteyn, Y.; Rabadi, L.; Parikh, R.; Bullock, P. Comparison of alamar blue and MTT assays for high through-put screening. Toxicol. Vitr. 2004, 18, 703-710. [CrossRef]

46. Huang, K.T.; Chen, Y.H.; Walker, A.M. Inaccuracies in MTS Assays: Major Distorting Effects of Medium, Serum Albumin, and Fatty Acids. Biotechniques 2004, 37, 406-412. [CrossRef]

47. Scarcello, E.; Lambremont, A.; Vanbever, R.; Jacques, P.J.; Lison, D. Mind Your Assays: Misleading Cytotoxicity with the WST-1 Assay in the Presence of Manganese. PLoS ONE 2020, 15, e0231634. [CrossRef]

48. Aslantürk, Ö.S. In Vitro Cytotoxicity and Cell Viability Assays: Principles, Advantages, and Disadvantages. In Genotoxicity-A Predictable Risk to Our Actual World; IntechOpen: London, UK, 2017. [CrossRef]

49. Vichai, V.; Kirtikara, K. Sulforhodamine B Colorimetric Assay for Cytotoxicity Screening. Nat. Protoc. 2006, 1, 1112-1116. [CrossRef]

50. Amaani, R.; Dwira, S. Phytochemical Content an in Vitro Toxicity of Glycine Soja Ethanol Extract on the A549 Lung Cancer Line Cell. J. Phys. 2018, 1073, 32042. [CrossRef] 
51. El-Azab, A.S.; Abdel-Aziz, A.A.M.; Abou-Zeid, L.A.; El-Husseiny, W.M.; ElMorsy, A.M.; El-Gendy, M.A.; El-Sayed, M.A.A. Synthesis, antitumour activities and molecular docking of thiocarboxylic acid ester-based NSAID scaffolds: COX-2 inhibition and mechanistic studies. J. Enzym. Inhib. Med. Chem. 2018, 33, 989-998. [CrossRef]

52. Michel, K.H.; Chaney, M.O.; Jones, N.D.; Hoehn, M.M.; Nagarajan, R. Epipolythiopiperazinedione Antibiotics from Penicillium Turbatum. J. Antibiot. 1974, 27, 57-64. [CrossRef]

53. Stillwell, M.A.; Magasi, L.P.; Strunz, G.M. Production, Isolation, and Antimicrobial Activity of Hyalodendrin, a New Antibiotic Produced by a Species of Hyalodendron. Can. J. Microbiol. 2011, 20, 759-764. [CrossRef]

54. Andreani, A.; Burnelli, S.; Granaiola, M.; Leoni, A.; Locatelli, A.; Morigi, R.; Rambaldi, M.; Varoli, L.; Landi, L.; Prata, C.; et al. Antitumor activity of bis-indole derivatives. J. Med. Chem. 2008, 51, 4563-4570. [CrossRef] [PubMed]

55. Kim, D.J.; Reddy, K.; Kim, M.O.; Li, Y.; Nadas, J.; Cho, Y.Y.; Kim, J.E.; Shim, J.H.; Song, N.R.; Carper, A.; et al. (3-Chloroacetyl)Indole, a Novel Allosteric AKT Inhibitor, Suppresses Colon Cancer Growth in Vitro and in Vivo. Cancer Prev. Res. 2011, 4, 1842-1851. [CrossRef] [PubMed]

56. Chen, C.-S.; Weng, D.; Weng, J.-R. Potent Indole-3-Carbinol-Derived Antitumor Agents-Google Patents. US7807705B2, October 2010.

57. McArthur, K.A.; Mitchell, S.S.; Tsueng, G.; Rheingold, A.; White, D.J.; Grodberg, J.; Lam, K.S.; Potts, B.C.M. Lynamicins A-E, Chlorinated Bisindole Pyrrole Antibiotics from a Novel Marine Actinomycete. J. Nat. Prod. 2008, 71, 1732-1737. [CrossRef] [PubMed]

58. Gang, D.; Kim, D.W.; Park, H.S. Cyclic Peptides: Promising Scaffolds for Biopharmaceuticals. Genes 2018, 9, 557. [CrossRef]

59. Avendaño, C.; Menéndez, J.C. Anticancer Drugs Acting via Radical Species, Photosensitizers and Photodynamic Therapy of Cancer. Med. Chem. Anticancer. Drugs 2008, 93-138. [CrossRef]

60. Marqus, S.; Pirogova, E.; Piva, T.J. Evaluation of the use of therapeutic peptides for cancer treatment. J. Biomed. Science. $2017,24,21$. [CrossRef] 